\title{
Pengaruh Gaya Kepemimpinan, Situasi Kepemimpinan, Iklim Kerja Organisasi, Terhadap Kinerja Karyawan pada PT. Berlina Plastik Pandaan.
}

\author{
Hariyanto \\ Dosen STIE Malangkucecwara \\ Jalan Terusan Candi Kalasan Malang \\ Telp. (0341) 491813
}

\begin{abstract}
:
Nowadays, the relationship between leader and subordinates is very decisive work climate organization, with a good work organization climate then the production process becomes smooth, sales targets are met so that corporate goals can be achieved. Sample In this is the employees of PT. Berlina Plastik Pandaan. The analysis method is path analysis. The results of his research are: (1) The change of leadership style (XI) has a positive and significant effect on the organizational climate change cluster (Y1). the leadership situation (X2) has a positive and significant effect on the organizational climate change (Y1). indirect influence between the variables of leadership style (X1), leadership situation (X2), on employee performance variable (Y2) through the influence of organizational climate (Y1), it can be concluded that: coefficient path calculation indirect influence, style of leadership (X1) on employee performance (Y2) through organizational climate change cluster (Y1).

Keywords: Organization, Leadership, Working Climate
\end{abstract}

\section{PENDAHULUAN}

\section{Latar Belakang Permasalahan}

Kepemimpinan adalah proses mempengaruhi dalam menentukan tujuan organisasi, memotivasi perilaku pengikut untuk mencapai tujuan, mempengaruhi untuk memperbaiki kelompok dan budayanya. Pimpinan perusahaan yang berkaitan langsung dengan aktivitas perusahaan seperti manajer, staf, mandor sampai pada ketua kelompok kerja merupakan orang yang bertanggung jawab langsung pada kelancaran proses produksi sampai pada penjualan pimpinan memiliki wewenang penuh sesuai dengan ketentuan atau peraturan yang berlaku pada perusahaan untuk menggunakan segala sumber daya yang ada untuk menjalankan aktivitas perusahaan.

Gaya kepemimpinan adalah sekumpulan ciri yang digunakan pimpinan untuk mempengaruhi bawahan agar sasaran organisasi tercapai atau dapat pula dikatakan bahwa gaya kepemmpinan adalah pola perilaku dan strategi yang disukai dan sering diterapkan oleh seorang pemimpin. Dengan pemilihan gaya kepemimpinan yang tepat maka pimpinan diharapkan dapat 
memaksimumkan produktivitas, menciptakan kepuasan kerja, menciptakan pertumbuhan dan dapat menyesuaikan dengan segala situasi.

Selain gaya kepemimpinan, situasi kepemimpinan merupakan faktor lain yang diperlukan untuk mencapai iklim kerja organsiasi yang baik. Situasi kepemimpinan adalah metode atau cara pendekatan yang dilakukan pimpinan organsiasi terhadap anggotanya dalam hal ini pekerja atau karyawan untuk mengatasi keadaan dan kondisi yang terjadi atau dialami pekerja demi tercapainya efektivitas dalam aktivitas/kegiatan perusahaan. Dengan pemilihan situasi kepemimpinan yang baik maka tercapai efektivitas yang berpengaruh pada kelancaran proses produksi.

Iklim kerja organisasi adalah situasi dan kondisi yang terjadi dalam tubuh organisasi di mana di dalamnya terdapat sistem kepengurusan yang jelas, kegiatan organisasi berjalan dengan lancar, kejelasan dalam penyampaian informasi, instruksi perintah dan pendapat, serta kejelasan dalam penerapan tugas dan wewenang sesuai dengan peraturan yang telah disepakati dalam organisasi sehingga tujuan organisasi dapat tercapai. Untuk mencapai iklim kerja organisasi yang baik maka seorang pemimpin diharapkan dapat memilih gaya kepemimpinan dan situasi kepemimpinan yang tepat. Dengan iklim kerja organisasi yang baik maka pimpinan dapat memaksimumkan produktivitas, menciptakan kepuasan kerja, menciptakan pertumbuhan dan dapat menyesuaikan dengan segala situasi sehingga kegiatan produkti dapat berjalan dengan lancar, target penjualan yang maksimal terpenuhi dan tujuan dari organsiasi perusahaan dapat tercapai.

\section{TINJAUAN PUSTAKA}

\section{Teori dan Model Kepemimpinan Teori Sifat}

Teori yang berusaha untuk mengidentifikasikan karakteristik khas (fisik, mental, kepribadian) yang dikaitkan dengan keberhasilan kepemimpinan. Teori ini menekankan pada atribut-atribut pribadi dari para pemimpin. Teori ini didasarkan pada asumsi bahwa beberapa orang merupakan pemimpin alamiah dan dianugerahi beberapa ciri yang tidak dipunyai orang lain seperti energi yang tiada habis-habisnya, intuisi yang mendalam, pandangan masa depan yang luar biasa dan kekuatan persuasif yang tidak tertahankan. Teori kepemimpinan ini menyatakan bahwa keberhasilan manajerial disebabkan karena memiliki kemampuan-kemampuan luar biasa dari seseorang pemimpin. Adapun yang berkaitan dengan hal tersebut adalah: (1) Inteligensia; (2) Kepribadian; dan (3) Karakteristik fisik. 


\section{Teori Kepribadian Perilaku}

Di akhir tahun 1940-an para peneliti mulai mengeksplorasi pemikiran bahwa bagaimana perilaku seseorang dapat menentukan keefektifan kepemimpinan seseorang. Dan mereka menemukan sifat-sifat, mereka meneliti pengaruhnya pada prestasi dan kepuasan dari pengikutpengikutnya (a) Studi dari University of Michigan meliputi: (1) Pemimpin yang job-centered, dan (2) Pemimpin yang berpusat pada bawahan. (b) Studi dari Ohio State University, meliputi antara lain: (1) Membentuk struktur, dan (2) Konsiderasi.

\section{Teori Kepemimpinan Situasional}

Suatu pendekatan terhadap kepemimpinan yang menyatakan bahwa pemimpin memahami perilakunya, sifat-sifat bawahannya, dan situasi sebelum menggunakan suatu gaya kepemimpinan tertentu. Pendekatan ini mensyaratkan pemimpin untuk memiliki keterampilan diagnostik dalam perilaku manusia.

Menutup tinjauan mengenai teori kepemimpinan yatiu dengan menyajikan tiga pendekatan lebih baru terhadap persoalan: suatu teori atribusi kepemimpinan, kepemimpinan karismatik, dan kepemimpinan transaksional lawan transformasional: (1) Teori atribusi kepemimpinan, (2) Teori kepemimpinan karismatik, (3) Teori kepemimpinan karismatik, dan (4) Kepemimpinan transaksional lawan transformasional

\section{Gaya Kepemimpinan}

Gaya artinya sikap, gerakan, tingkah laku, sikap yang elok, gerak-gerik yang bagus, kekuatan, kesanggupan untuk berbuat baik. Sedangkan gaya kepemimpinan adalah sekumpulan ciri yang digunakan pimpinan untuk mempengaruhi bawahan agar sasaran organisasi tercapai atau dapat pula dikatakan bahwa gaya kepemimpinan adalah pola perilaku dan strategi yang disukai dan sering diterapkan oleh seorang pemimpin.

Gaya kepemimpinan adalah pola menyeluruh dari tindakan seorang pemimpin, baik yang tampak maupun yang tidak tampak oleh bawahanya. Gaya kepemimpinan menggambarkan kombinasi yang konsisten dari falsafah, keterampilan, sifat, dan sikap yang mendasari perilaku seseorang. Gaya kepemimpinan yang menunjukkan, secara langsung maupun tidak langsung, tentang keyakinan seorang pimpinan terhadap kemampuan bawahannya. Artinya, gaya kepemimpinan adalah perilaku dan strategi, sebagai hasil kombinasi dari falsafah, keterampilan, sifat, sikap, yang sering diterapkan seorang pemimpin ketika ia mencoba mempengaruhi kinerja bawahanya. 
Untuk menentukan gaya yang paling efektif dalam menghadapi keadaan tertentu maka perlu mempertimbangkan kekuatan yang ada dalam tiga unsur, yaitu: (1) Diri pemimpin, (2) Bawahan, dan (3) Situasi secara menyeluruh. Pada tahun 1960-an berkembang teori kepemimpinan yang dinamakan "pola manajerial". Kepemimpinan dipengaruhi oleh dua perhatian manajerial yang mendasar, yaitu perhatian terhadap produksi atau tugas dan perhatian terhadap manusia. Menurut teori ini ada empat gaya dasar kepemimpinan : (1) Gaya manajemen tugas, pemimpin menunjukkan perhatian tinggi terhadap produksi tetapi perhatian rendah terhadap manusia, (2) Gaya manajemen country club, pemimpin memperlihatkan perhatian yang tinggi terhadap manusia tetapi perhatian rendah terhadap produksi, (3) Gaya manajemen miskin, pemimpin tidak terlalu menunjukkan perhatian, baik terhadap produksi maupun manusia, (4) Gaya manajemen tim, pemimpin menunjukkan perhatian tinggi baik terhadap produksi maupun terhadap manusia. Menurut teori ini gaya manajemen tim, yang pada dasarnya sama dengan gaya demokratis merupakan gaya kepemimpinan yang baik untuk semua orang dalam segala situasi.

Sementara itu menurut Contigency Theory Leadership menyatakan bahwa ada kaitan antara gaya kepemimpinan dengan situasi tertentu yang dipersyaratkan. Menurut teori ini seorang pemimpin akan efektif jika gaya kepemimpinannya sesuai dengan situasi yang terjadi. Pendekatan ini menyarankan bahwa diperlukan dua perangkat perilaku untuk kepemimpinan yang efektif yaitu perilaku tugas dan perilaku hubungan. Dengan kedua perangkat ini maka kemungkinan akan melahirkan empat gaya kepemimpinan, yaitu: (1) Mengarahkan, gaya kepemimpinan ini perilaku tugas tinggi, perilaku hubungan rendah, (2) Menjual, perilaku tugas maupun perilaku huungan sama tinggi, (3) Ikut serta, perilaku tugas rendah sedangkan perilaku hubungan tinggi, dan (4) Mendelegasikan, baik perilaku tugas maupun perilaku hubungan sama rendah.

Path-Goal Model sepaham dengan pendapat di atas, bahwa suksesnya seorang pemimpin tergantung pada kemampuannya dalam menyesuaikan gaya kepemimpinannya dengan lingkungan dan karakteristik individual bawahannya. Sedangkan pengembangan baru dari teori ini yang dapat dikatakan sebagai kalangan moderat, menggambarkan bahwa ada empat tipe atau gaya kepemimpinan yaitu : (1) Mengarahkan, gaya ini saya dengan gaya otokratis, jadi bawahan mengetahui secara peris apa yang diharapkan dari mereka; (2) Mendukung, pemimpin bersifat ramah terhadap bawahan; (3) Berpartisipasi, pemimpin bertanya dan menggunakan saran bawahan; dan (4) Berorientasi pada tugas, pemimpin menyusun serangkaian tujuan yang menantang untuk bawahannya. 
Meskipun demikian diakui bahwa dalam manajemen modern, gaya kepemimpinan yang paling tepat untuk dikembangkan adalah gaya kepemimpinan yang partisipatif atau fasilitatif, serta involvement-oriented style yang terpusat pada komitmen dan keterlibatan pegawai. Akhirnya, gaya kepemimpinan dibagi dalam dua dimensi yaitu dimensi tugas dan dimensi manusia. Dimensi tugas disebut mengarahkan, berorientasi pada produk dan berujung pada gaya kepemimpinan otokratis, sedangkan dimensi manusia, berhubungan dengan istilah" mendukung berorientasi pada bawahan, berujung pada tipe kepemimpinan bebas kendali.

\section{Kepemimpinan Situasional atau Situasi Kepemimpinan}

Suatu pendekatan terhadap kepemimpinan yang menyatakan bahwa semua kepemimpinan tergantung kepada keadaan atau situasi. Situasi adalah gelanggang yang perlu bagi pemimpin untuk beroperasi. Bagi sebagian besar manajer, situasi bisa menentukan keberhasilan atau kegagalan, tetapi adalah keliru untuk terlalu menyalahkan situasi. Dalam menerapkan teori kepemimpinan situasional, manajer harus didasarkan pada hasil analisis terhadap situasi yang dihadapi pada suatu saat tertentu dan mengidentifikasikan kondisi anggota atau anak buah yang dipimpinnya. Kondisi bawahan merupakan faktor yang penting pada kepemimpinan situasional karena bawahan selain sebagai individu mereka juga merupakan kelompok yang kenyataannya dapat menentukan kekuatan pribadi yang dipunyai pemimpin. Beberapa model kepemimpinan situasional yaitu: (1) Model Kepemimpinan Kontingensi (Leadership Contigency Model) (Suatu pemutakiran terhadap model kepemimpinan Fred E. Fielder), dan (2) Model Kepemimpinan Situasional Menurut Hersey dan Blanchard

\section{Iklim Kerja Organisasi}

Iklim kerja organisasi adalah situasi dan kondisi yang terjadi dalam tubuh organisasi di mana di dalamnya terdapat sistem kepengurusan yang jelas, kegiatan organisasi berjalan dengan lancar, kejelasan dalam penyampaian informasi, instruksi perintah dan pendapat, serta kejelasan dalam penerapan tugas dan wewenang sesuai dengan peraturan yang telah disepakati dalam organisasi sehingga tujuan organisasi dapat tercapai.

\section{Kinerja}

\section{Faktor yang Mempengaruhi Kinerja}

Menurut Mathis dan Jackson (2006) kinerja seseorang tergantung tiga faktor yaitu: kemampuan untuk mengerjakan pekerjaannya, tingkat usaha, dan dukungan yang diberikan pada seseorang. Mathis dan Jackson (2006) mengenai kinerja individu dapat dilihat sebagaimana dalam Gambar 1 berikut ini: 


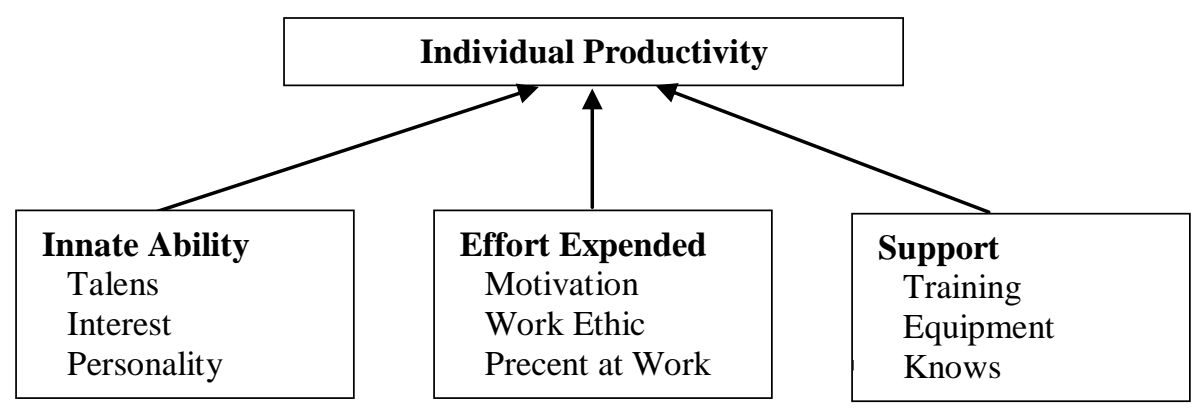

\section{Gambar 1: Produktivitas Individu (Karyawan/kelompok kerja)}

Berdasarkan gambar di atas, menunjukan bahwa produktivitas individu dipengaruhi oleh tiga faktor yaitu: (1) Innate ability, meliputi: bakat (talens), minat (interest), faktor kepribadian (personality factors), dan faktor fisik (physical factors); (2) Usaha (effort expended), meliputi: motivasi (motivation), etika kerja (work ethtic), penampilan kerja (precent at work), dan desain pekerjaan (job design); (3) Dorongan (support), yang meliputi: pelatihan (training), perlengkapan (equipment) (sarana, prasarana), harapanharapan organisasi yang dipahami (knows expectations), dan produktivitas kelompok kerja (productive teammates).

Kinerja merupakan penjumlahan dari motivasi dengan kemampuan, dan dipengaruhi juga oleh kondisi kerja. Robbins (2003) menyatakan bahwa motivasi sebagai adanya kesediaan individu atau karyawan untuk mengeluarkan tingkat upaya yang tinggi kearah pencapaian tujuan-tujuan orgnaisasi. Motivasi merupakan penggerak yang mengarahkan orang pada pencapaian tujuan. Tinggi rendahnya motivasi seseorang berkaitana erat dengan tinggi rendahnya kinerja seseorang.

Kemampuan (ability) merupakan faktor kedua yang mempengaruhi kinerja karyawan. Kemampuan adalah suatu kapasitas individu untuk mengerjakan suatu pekerjaan (Robbins, 2003). Menurut Gibson et.al. (2000) kemampuan potensi orang untuk melaksanakan tugas atau pekerjaan. Menurut Davis (1995) kemampuan merupakan pengetahuan seseorang dan ketrampilan dalam menerapkan pengetahuan. Dengan kata lain merupakan fungsi dari pengetahuan (knowledge) dan ketrampilan (skill). Lebih lanjut Amstrong (2006) menyatakan bahwa kemampuan tidak saja mempengaruhi kinerja tapi dapat juga mempengaruhi kepuasan kerja dan keinginan untuk tetap tinggal dalam suatu organisasi.

\section{Ukuran Kinerja}

Bernadin dan Russel (2001) mengemukan terdapat enam kriteria primer yang dapat digunakan untuk mengukur kinerja pegawai. Keenam kriteria 
tersebut adalah quality, quantity, timeliness, cost effectiveness, need for supervisor dan interpersonal impact. Keenan kriteria ini dijelaskan satu persatu berikut: (1) Quality, merupakan tingkat sejauhmana proses atau hasil pelaksanaan kegiatan mendekati kesempurnaaan atau mendekati tujuan yang diharapkan; (2) Quantity, merupakan jumlah yang dihasilkan, misalnya jumlah rupiah, jumlah unit, atau siklus kegiatan diselesaikan; (3) Timeliness, merupakan lamanya suatu kegiatan diselesaikan pada waktu yang dikehendaki, dengan memperhatikan jumlah out put lain serta waktu yang tersedia untuk kegiatan lain; (4) Cost Effectiveness, besarnya penggunaan sumberdaya organisasi guna mencapai hasil yang maksimal atau pengurangan kerugian dari setiap unit penggunaan sumberdaya; (5) Need for supervision, kemampuan pegawai untuk melaksanakan fungsi pekerjaan tanpa memerlukan pengawasan seorang supervisior untuk mencegah tindakan yang kurang diinginkan; dan (6) Interpersonal impact, kemampuan seorang pegawai untuk memelihara harga diri, nama baik dan kemampuan kerjasama di antara rekan kerja dan bawahan.

\section{Hipotesis Penelitian}

Berdasarkan pada landasan teori yang ada, maka dapat dikemukakan hipotesis sebagai berikut:

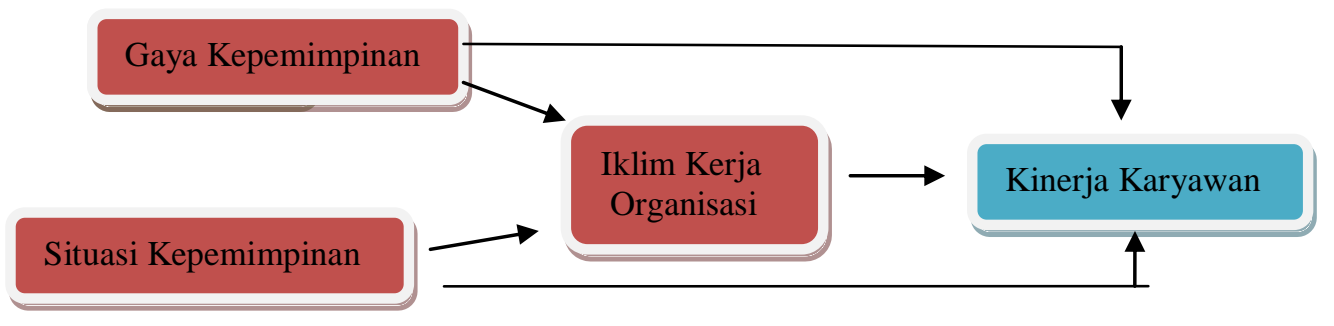

\section{Gambar 2: Hipotesis Penelitian}

Dari model hipotesis, dapat disusun hipotesis penelitiannya sebagai berikut:

$\mathrm{H}_{1}$ : Diduga bahwa gaya kepemimpinan $\left(\mathrm{X}_{1}\right)$ ada pengaruh bermakna terhadap kinerja karyawan ( $\left.\mathrm{Y}_{2}\right)$

$\mathrm{H}_{2}$ : Diduga bahwa situasi kepemimpinan $\left(\mathrm{X}_{2}\right)$ ada pengaruh bermakna terhadap kinerja karyawan ( $\left.\mathrm{Y}_{2}\right)$

$\mathrm{H}_{3}$ : Diduga bahwa gaya kepemimpinan $\left(\mathrm{X}_{1}\right)$, ada pengaruh bermakna terhadap iklim kerja organisasi $\left(\mathrm{Y}_{1}\right)$

$\mathrm{H}_{4}$ : Diduga bahwa situasi Diduga akepemimpinan $\left(\mathrm{X}_{2}\right)$, ada pengaruh bermakna terhadap iklim Kerja organisasi $\left(\mathrm{Y}_{1}\right)$

$\mathrm{H}_{5}$ : Diduga bahwa iklim kerja organisasi ( $\left.\mathrm{Y}_{1}\right)$ ada pengaruh bermakna terhadap kinerja karyawan ( $\left.\mathrm{Y}_{2}\right)$ 
$\mathrm{H}_{6}$ : Diduga ada pengaruh iklim kerja organisasi $\left(\mathrm{Y}_{1}\right)$ secara tidak langsung dalam hubungannya dengan gaya kepemimpinan $\left(\mathrm{X}_{1}\right)$ terhadap kinerja karyawan $\left(\mathrm{Y}_{2}\right)$ secara bermakna

$\mathrm{H}_{7}$ : Diduga ada pengaruh iklim kerja organisasi $\left(\mathrm{Y}_{1}\right)$ secara tidak langsung dalam hubungannya dengan situasi kepemimpinan $\left(\mathrm{X}_{2}\right)$ terhadap kinerja karyawan ( $\left.\mathrm{Y}_{2}\right)$ secara bermakna

\section{METODE PENELITIAN}

\section{Peubah dan Pengukuran}

Peubah yang digunakan dalam penelitian ini adalah: (1) Gaya kepemimpinan $\left(\mathrm{X}_{1}\right)$, dengan item-item: kepemimpinan direktif, kepemimpinan suportif, dan kepemimpinan partisipatif; (2) Situasi kepemimpinan $\left(\mathrm{X}_{2}\right)$, meliputi item-itemnya: hubungan pemimpin dengan anggota, tugas-tugas, dan posisi kekuasaan. Sedangkan peubah antara adalah: iklim kerja organisasi ( $\left.\mathrm{Y}_{1}\right)$, dengan indikator yaitu otonomi, fleksibilitas, kepercayaan, keterbukaan, simpatik, dukungan, kejujuran menghargai, kejelasan tujuan, pekerjaan, risiko, dan pertumbuhan kepribadian. Berdasarkan Indikator tersebut, diketahui item-itemnya yaitu kebebasan berpendapat, kepercayaan, keterbukaan atau rasa kesetiakawanan. Selanjutnya Kinerja karyawan $\left(\mathrm{Y}_{2}\right)$ dengan tingkat aktivitas, sedangkan itemnya adalah: melakukan kegiatan yang efektif, melakukan kegiatan yang efisien, dan mampu membagi dan menyelesaikan tugas dan bekerja sama dalam tim (manajemen tim yang baik)

\section{Populasi Dan Penentuan Sampel}

Populasi adalah wilayah generalisasi, yang terdiri dari obyek atau subyek yang mempunyai kualitas dan karakteristik tertentu dan diterapkan oleh peneliti untuk dipelajari dan kemudian untuk ditarik kesimpulan (Sugiyono, 2008). Adapun populasi dalam penelitian ini adalah seluruh jumlah karyawan PT. Berlina Plastik Pandaan. Sedangkan sampel dalam penelitian ini adalah menurut Roscoe (1982) apabila dalam penelitian metode analisis yang digunakan adalah multivariate (korelasi atau regresi berganda misalnya), maka jumlah anggota sampel minimal 10 kali dari jumlah variabel yang diteliti. misalnya variabel penelitiannya ada 5 (independen + dependen), maka jumlah anggota sampel $=10 \times 5=50$ (Sugiyono, 2008). Berdasarkan keterangan di atas maka 50 orang karyawan, dan untuk validnya data jumlah sampel ditentukan oleh peneliti sebanyak 50 orang karyawa tersebut, dipilih secara acak dari masing-masing bagian pada PT. Berlina Plastik Pandaan

\section{Metode Analisis}

\section{Analisis Deskriptif}

Analisis ini digunakan untuk mendeskriptifkan karakteristik penelitian dengan menggambarkan obyek penelitian, meliputi responden yang diteliti, 
serta item-item yang didistribusikan dari masing-masing peubah. Setelah seluruh data yang diperlukan diperoleh, selanjutnya adalah mengolah data, kemudian mentabulasikan ke dalam tabel. Tahap berikutnya adalah membahas data yang diperoleh tersebut secara deskriptif. Ukuran deskriptif adalah dengan pemberian angka, baik dalam jumlah responden maupun dalam angka presentase.

\section{Analisa Jalur (path analysis)}

Analisis jalur (path analysis) digunakan untuk mengukur besarnya kontribusi atau pengaruh peubah bebas terhadap peubah tergantung, baik pengaruh secara langsung maupun pengaruh secara tidak langsung melalui hubungan dengan peubah bebas lainnya (Arikunto,2006).

\section{HASIL PENELITIAN DAN PEMBAHASAN}

\section{Analisis Data Path}

Analisis jalur (path analysis) dalam penelitian ini dipilih untuk mengukur besarnya kontribusi atau pengaruh peubah bebas terhadap peubah tergantung, baik pengaruh secara langsung maupun pengaruh secara tidak langsung melalui hubungan dengan peubah bebas lainnya. Pengujian hipotesis dengan menggunakan analisis jalur, seperti yang dijelaskan berikut ini:

\section{Model Konsep Path}

Berdasarkan hubungan antar peubah secara teoritis, dapat dibuat model dari konsep dan teori sebagai berikut:

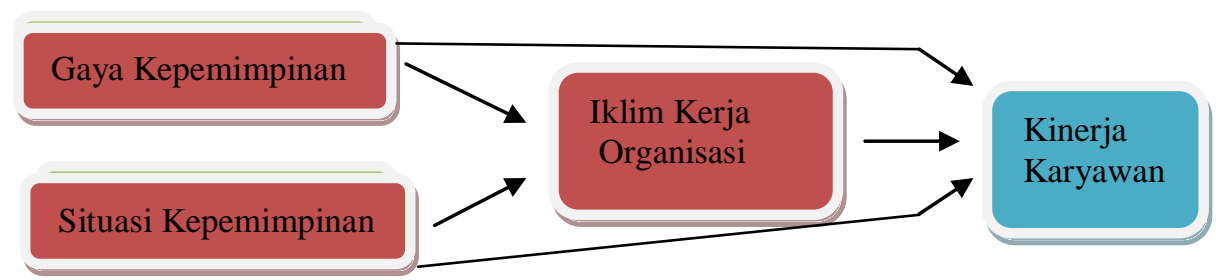

\section{Gambar 3: Model Konsep Path}

Analisis path peubah gaya kepemimpinan $\left(\mathrm{X}_{1}\right)$, peubah situasi kepemimpinan $\left(\mathrm{X}_{2}\right)$, iklim kerja organisasi $\left(\mathrm{Y}_{1}\right)$, terhadap kinerja karyawan $\left(\mathbf{Y}_{2}\right)$

Berdasarkan analisis maka hasilnya adalah sebagai berikut:

Tabel 1: Hasil Analisis Path

\begin{tabular}{|l|c|c|c|c|c|}
\hline \multicolumn{2}{|c|}{ Peubah } & Stand. & $\mathrm{t}$ & Prob. & $\begin{array}{c}\text { Keputusan } \\
\text { Terhadap } \mathrm{H}_{0}\end{array}$ \\
\hline \multicolumn{1}{|c|}{ Bebas } & Terikat & hitung & Kaya \\
Kepemimpinan & $\begin{array}{c}\text { Kinerja } \\
\text { Karyawan }\end{array}$ & 0,287 & 2,449 & 0,018 & DITOLAK \\
\cline { 2 - 3 } & &
\end{tabular}




\begin{tabular}{|c|c|c|c|c|c|}
\hline$\left(\mathrm{X}_{1}\right)$ & \multirow{3}{*}{$\left(\mathrm{Y}_{2}\right)$} & & & & \\
\hline $\begin{array}{l}\text { Situasi } \\
\text { Kepemimpinan } \\
\left(\mathrm{X}_{2}\right)\end{array}$ & & 0,289 & 2,569 & 0.014 & DITOLAK \\
\hline $\begin{array}{l}\text { Iklim Kerja } \\
\text { Organisasi }\left(\mathrm{Y}_{1}\right)\end{array}$ & & 0,384 & 3,632 & 0.012 & DITOLAK \\
\hline Konstanta & $:-1,681$ & & & & \\
\hline $\mathrm{R}$ & $: 0.843$ & & & & \\
\hline R Square & $: 0.711$ & & & & \\
\hline Adjusted R Square & $: 0.692$ & & & & \\
\hline$F_{\text {hitung }}$ & $: 37,781$ & & & & \\
\hline Probabilitas & $: 0,000$ & & & & \\
\hline $\mathrm{n}$ & $: 50$ & & & & \\
\hline
\end{tabular}

Dari hasil analisis path pada tabel di atas maka persamaan regresi sebagai berikut:

Kinerja Karyawan $=0,287 \mathrm{X}_{1}+0,289 \mathrm{X}_{2}+0,384 \mathrm{Y}_{1}-1,681$

Analisis path peubah gaya kepemimpinan $\left(\mathrm{X}_{1}\right)$, peubah situasi kepemimpinan $\left(\mathrm{X}_{2}\right)$, terhadap peubah iklim kerja organisasi $\left(\mathrm{Y}_{1}\right)$

Hasil analisis path antara peubah gaya kepemimpinan $\left(\mathrm{X}_{1}\right)$, peubah situasi kepemimpinan $\left(\mathrm{X}_{2}\right)$, terhadap peubah iklim kerja organisasi $\left(\mathrm{Y}_{1}\right)$ dapat dilihat pada tabel di bawah ini:

Tabel 2:Hasil analisis path antara peubah gaya kepemimpinan $\left(X_{1}\right)$, peubah situasi kepemimpinan $\left(X_{2}\right)$, terhadap peubah iklim kerja organisasi $\left(\mathbf{Y}_{1}\right)$

\begin{tabular}{|c|c|c|c|c|c|}
\hline \multicolumn{2}{|c|}{ Peubah } & \multirow{2}{*}{$\begin{array}{l}\text { Stand. } \\
\text { Coeff. }\end{array}$} & \multirow{2}{*}{ t hitung } & \multirow{2}{*}{ Prob. } & \multirow{2}{*}{$\begin{array}{c}\text { Keputusan } \\
\text { Terhadap } \\
\mathrm{H}_{0} \\
\end{array}$} \\
\hline Bebas & Terikat & & & & \\
\hline $\begin{array}{l}\text { Gaya } \\
\text { Kepemimpinan } \\
\left(\mathrm{X}_{1}\right)\end{array}$ & \multirow{2}{*}{$\begin{array}{c}\text { Iklim Kerja } \\
\text { Organisasi } \\
\qquad\left(\mathrm{Y}_{1}\right)\end{array}$} & 0,514 & 5,705 & 0.000 & DITOLAK \\
\hline $\begin{array}{l}\text { Situasi } \\
\text { Kepemimpinan } \\
\left(\mathrm{X}_{2}\right)\end{array}$ & & 0,463 & 5,137 & 0.000 & DITOLAK \\
\hline $\begin{array}{l}\text { Konstanta } \\
\mathrm{R} \\
\mathrm{R} \text { Square } \\
\text { Adjusted R Square } \\
\mathrm{F}_{\text {hitung }} \\
\text { Probabilitas } \\
\mathrm{n}\end{array}$ & $\begin{array}{l}:-13,60 t \\
: 0.840 \\
: 0.705 \\
: 0.692 \\
: 56,142 \\
: 0,000 \\
: 50 \\
\end{array}$ & & & & \\
\hline
\end{tabular}

Dari hasil analisis path pada tabel diatas maka persamaan regresi sebagai berikut: 
Iklim kerja organisasi $=0,514 \mathrm{X}_{1}+0,463 \mathrm{X}_{2}$

\section{Analisis path kepuasan kerja $\left(\mathbf{Y}_{1}\right)$ terhadap kinerja karyawan $\left(\mathbf{Y}_{2}\right)$}

Hasil analisis path antara iklim kerja organisasi $\left(\mathrm{Y}_{1}\right)$ terhadap peubah kinerja karyawan $\left(\mathrm{Y}_{2}\right)$ dapat dilihat pada tabel berikut ini:

Tabel 3: Hasil analisis path antara peubah iklim kerja organisasi $\left(Y_{1}\right)$ terhadap peubah kinerja karyawan $\left(\mathbf{Y}_{2}\right)$

\begin{tabular}{|l|c|c|l|l|c|}
\hline \multicolumn{1}{|c|}{ Peubah } & $\begin{array}{c}\text { Standarized } \\
\text { Coefficient }\end{array}$ & t hitung & Prob. & $\begin{array}{c}\text { Keputusan } \\
\text { Terhadap } \mathrm{H}_{0}\end{array}$ \\
\hline $\begin{array}{l}\text { Iklim Kerja } \\
\text { Organisasi } \\
\left(\mathrm{Y}_{1}\right)\end{array}$ & $\begin{array}{c}\text { Kinerja } \\
\text { Karyawan } \\
\left(\mathrm{Y}_{2}\right)\end{array}$ & 0,799 & 9,214 & 0.000 & DITOLAK \\
\cline { 1 - 3 } Konstanta & $: 3,652$ & & \\
R & $: 0.799$ & & \\
R Square & $: 0.639$ & & \\
Adjusted R Square & $: 0.631$ & & \\
$\mathrm{~F}_{\text {hitung }}$ & $: 84,900$ & & \\
Probabilitas & $: 0.000$ & & \\
n & $: 50$ & & \\
\hline
\end{tabular}

Dari hasil analisis path pada tabel 10 diperoleh model persamaan regresi yang sudah dibakukan sebagai berikut:

$$
\text { Kinerja }=0,799 \mathrm{Y}_{1}
$$

\section{Model Lintasan Pengaruh}

Berdasarkan model-model pengaruh tersebut, dapat disusun model lintasan pengaruh dimana model lintasan ini disebut dengan analisis path, dan pengaruh error ditentukan sebagai berikut:

$$
\begin{aligned}
& \text { Regresi : Pe1 }=\sqrt{1-\mathrm{R}_{2 / 1}}=\sqrt{1-0,705}=0,543 \\
& \text { Regresi : Pe2 }=\sqrt{1-\mathrm{R}_{\mathbf{2} / \mathbf{2}}}=\sqrt{1-0,639}=0,799
\end{aligned}
$$

\section{Model Path}

Dari hasil analisis path, maka didapat model path sebagai berikut:

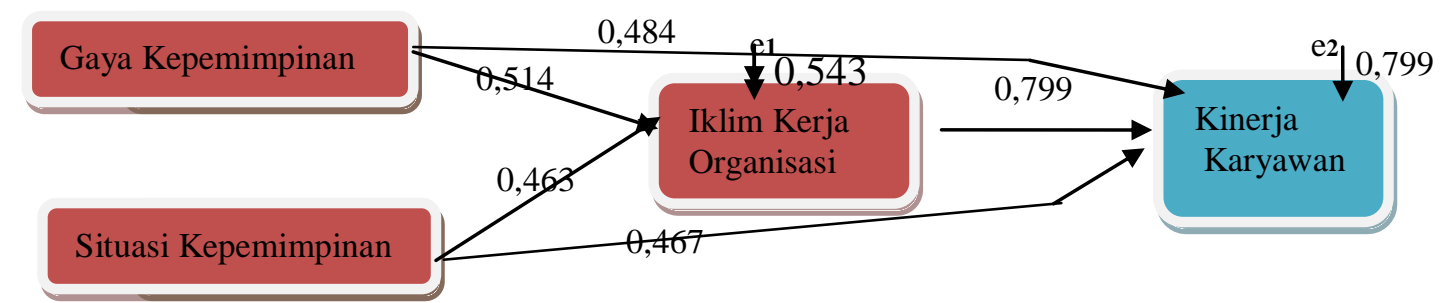

Gambar 4: Model Path I 
Koefisien determinasi total, yaitu:

$$
\mathbf{R}_{\mathbf{m}}^{\mathbf{2}}=\mathrm{P}_{\mathrm{e} 1}^{2} \mathrm{X} \mathrm{P}^{2} \mathbf{e} 2=1-\left(0,543^{2}\right)\left(0,799^{2}\right)=1-0,165=0,835
$$

Artinya keragaman data yang dapat dijelaskan oleh model analisis path tersebut adalah sebesar 0.835 atau $83.5 \%$ atau dengan kata lain informasi yang terkandung dalam data $83.5 \%$ dapat dijelaskan oleh model tersebut. Sedangkan sisanya, yaitu $0,165 \%$ dijelaskan oleh peubah lain (yang belum terdapat dalam model) dan error.

\section{Theory Triming}

Uji validasi keofisien path pada setiap jalur untuk pengaruh langsung adalah sama dengan pada regresi, menggunakan nilai $\mathrm{p}$ dari uji t yaitu pengujian koefisien regresi peubah dibakukan secara parsial.

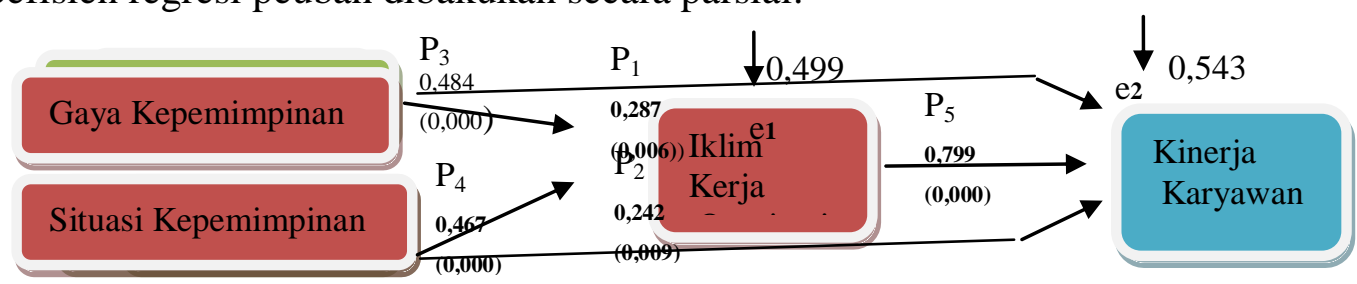

\section{Gambar 5: Model Path II}

Dari gambar di atas, dapat diambil kesimpulan theory trimming sebagai berikut:

Peubah gaya kepemimpinan $\left(\mathrm{X}_{1}\right)$ berpengaruh positif dan signifikan terhadap kinerja karyawan $\left(\mathrm{Y}_{2}\right) \rightarrow 0,484(0,000)$

Peubah situasi kepemimpinan $\left(\mathrm{X}_{2}\right)$ berpengaruh positif dan signifikan terhadap Peubah kinerja karyawan $\left(\mathrm{Y}_{2}\right) \rightarrow 0,467(0,000)$

Peubah gaya kepemimpinan $\left(\mathrm{X}_{1}\right)$ berpengaruh positif dan signifikan terhadap peubah kepuasan kerja karyawan $\left(\mathrm{Y}_{1}\right) \rightarrow 0,514(0,000)$

Peubah situasi kepemimpinan $\left(\mathrm{X}_{2}\right)$ berpengaruh positif dan signifikan terhadap peubah kepuasan kerja karyawan $\left(\mathrm{Y}_{1}\right) \rightarrow 0,463(0,000)$

Peubah iklim kerja organisasi $\left(\mathrm{Y}_{1}\right)$ berpengaruh positif dan signifikan terhadap peubah kinerja karyawan $\left(\mathrm{Y}_{2}\right) \rightarrow 0,799(0,000)$

\section{Koefisien Path Pengaruh Tidak Langsung}

Koefisien path pengaruh tidak langsung dapat diperoleh dengan cara sebagai berikut:

Peubah gaya kepemimpinan $\left(\mathrm{X}_{1}\right)$ terhadap peubah kinerja karyawan $\left(\mathrm{Y}_{2}\right)$ melalui peubah iklim kerja organisasi $\left(\mathrm{Y}_{1}\right) \rightarrow\left(\mathrm{P}_{3} \mathrm{X} \mathrm{P}_{5}\right)=0.562 \mathrm{X} 0.799=$ 0.449

Peubah gaya kepemimpinan $\left(\mathrm{X}_{2}\right)$ terhadap peubah kinerja kayawan $\left(\mathrm{Y}_{2}\right)$ melalui peubah iklim kerja organisasi $\left(\mathrm{Y}_{1}\right) \rightarrow\left(\mathrm{P}_{4} \mathrm{X} \mathrm{P}_{5}\right)=0,429 \mathrm{X} 0.799=$ 0.342 


\section{Koefisien Path Pengaruh Total}

Koefisien path pengaruh total, dihitung dengan cara yaitu:

Pengaruh total peubah gaya kepemimpinan $\left(\mathrm{X}_{1}\right)$ terhadap peubah kinerja karywan $\left(\mathrm{Y}_{2}\right)=0,484+0.799=1,283$

Pengaruh total peubah situasi kepemimpinan $\left(\mathrm{X}_{2}\right)$ terhadap kinerja karyawan $\left(\mathrm{Y}_{2}\right)=0.467+0.799=1,266$

\section{Pengujian Hipotesis}

Tabel 4: Perbandingan pengaruh langsung (direct effect) dan tidak langsung (indirect effect)

\begin{tabular}{|c|c|c|c|c|c|c|}
\hline $\begin{array}{c}\text { Peubah } \\
\text { Bebas }\end{array}$ & $\begin{array}{l}\text { Peubah } \\
\text { Terikat }\end{array}$ & $\begin{array}{l}\text { Direct } \\
\text { Effect }\end{array}$ & $\begin{array}{c}\text { Peubah } \\
\text { Antara }\end{array}$ & $\begin{array}{c}\text { Indirect } \\
\text { Effect }\end{array}$ & $\begin{array}{l}\text { Total } \\
\text { Effect }\end{array}$ & Ket. \\
\hline $\mathrm{X}_{1}$ & \multirow{3}{*}{$\mathrm{Y}_{2}$} & 0.384 & & & & \\
\hline$X_{2}$ & & 0.287 & & & & \\
\hline $\mathrm{Y}_{1}$ & & 0.289 & & & & \\
\hline $\mathrm{X}_{1}$ & \multirow{2}{*}{$\mathrm{Y}_{2}$} & 0.484 & $Y_{1}$ & $\begin{array}{c}0,484 \mathrm{x} \\
0,799 \\
=0,367\end{array}$ & $\begin{array}{c}0,812+ \\
0,840= \\
1.402\end{array}$ & $\begin{array}{l}\text { DE } \\
<\mathrm{IE}\end{array}$ \\
\hline$X_{2}$ & & 0.467 & $\mathrm{Y}_{1}$ & $\begin{array}{c}0,467 \mathrm{x} \\
0,799 \\
=0,373\end{array}$ & $\begin{array}{c}0.340+ \\
0.840= \\
1.269\end{array}$ & $\begin{array}{l}\mathrm{DE} \\
<\mathrm{IE}\end{array}$ \\
\hline
\end{tabular}

Ada Pengaruh Bermakna Peubah Gaya Kepemimpinan $\left(X_{1}\right)$ Terhadap Peubah Kinerja Karyawan $\left(\mathbf{Y}_{2}\right)$

Pengaruh langsung peubah gaya kepemimpinan $\left(\mathrm{X}_{1}\right)$ terhadap peubah kinerja karyawan $\left(\mathrm{Y}_{2}\right)$ dapat dilihat dari tingkat probabilitas yang dimiliki peubah tersebut, yaitu sebesar 0.006, sedangkan besarnya pengaruh peubah gaya kepemimpinan $\left(\mathrm{X}_{1}\right)$ terhadap peubah kinerja karyawan $\left(\mathrm{Y}_{2}\right)$ berdasarkan tabel regresi, yaitu sebesar 0.009 yang menunjuk pada angkaangka tersebut, maka dapat dijelaskan bahwa:

Peubah gaya kepemimpinan $\left(\mathrm{X}_{1}\right)$ terhadap peubah kinerja karyawan $\left(\mathrm{Y}_{2}\right)$, keputusannya adalah $\mathrm{H}_{0}$ ditolak, yang artinya terdapat pengaruh yang signifikan. Hal ini ditunjukkan dengan tingkat probabilitas dari peubah gaya kepemimpinan $\left(\mathrm{X}_{1}\right)$ sebesar 0.006 dimana nilai ini lebih kecil dari 0.05 $(\mathrm{P}<0.05)$.

Peubah gaya kepemimpinan $\left(\mathrm{X}_{1}\right)$ mempunyai pengaruh sebesar 0.287 terhadap peubah kinerja karyawan $\left(\mathrm{Y}_{2}\right)$.

Dari data tersebut maka hipotesis yang menyatakan bahwa ada pengaruh bermakna peubah gaya kepemimpinan $\left(X_{1}\right)$ terhadap peubah kinerja karyawan $\left(\mathrm{Y}_{2}\right)$ dapat diterima. 


\section{Ada Pengaruh Bermakna Peubah Situasi Kepemimpinan $\left(\mathrm{X}_{2}\right)$} Terhadap Peubah Kinerja Karyawan $\left(\mathbf{Y}_{2}\right)$

Pengaruh langsung peubah situasi kepemimpinan $\left(\mathrm{X}_{2}\right)$ terhadap peubah kinerja karyawan $\left(\mathrm{Y}_{2}\right)$ dapat dilihat dari tingkat probabilitas yang dimiliki peubah tersebut, yaitu sebesar 0.009 , sedangkan besarnya pengaruh peubah situasi kepemimpinan $\left(\mathrm{X}_{2}\right)$ terhadap peubah kinerja karyawan $\left(\mathrm{Y}_{2}\right)$ berdasarkan tabel regresi, yaitu sebesar 0.242 yang menunjuk pada angkaangka tersebut, maka dapat dijelaskan bahwa:

Peubah situasi kepemimpinan $\left(\mathrm{X}_{2}\right)$ terhadap peubah kinerja karyawan $\left(\mathrm{Y}_{2}\right)$, keputusannya adalah $\mathrm{H}_{0}$ ditolak, yang artinya terdapat pengaruh yang signifikan. Hal ini ditunjukkan dengan tingkat probabilitas dari peubah situasi kepemimpinan $\left(\mathrm{X}_{2}\right)$ sebesar 0.009 dimana nilai ini lebih kecil dari $0.05(\mathrm{P}<0.05)$.

Peubah situasi kepemimpinan $\left(\mathrm{X}_{2}\right)$ mempunyai pengaruh sebesar 0.242 terhadap peubah kinerja karyawan $\left(\mathrm{Y}_{2}\right)$.

Dari data di atas maka hipotesis yang menyatakan bahwa ada pengaruh bermakna situasi kepemimpinan $\left(\mathrm{X}_{2}\right)$ terhadap kinerja karyawan $\left(\mathrm{Y}_{2}\right)$ dapat diterima.

\section{Ada Pengaruh Bermakna Peubah Iklim Kerja Organisasi $\left(Y_{1}\right)$ Terhadap Peubah Kinerja Karyawan $\left(\mathrm{Y}_{2}\right)$}

Pengaruh langsung peubah iklim kerja organisasi $\left(\mathrm{Y}_{1}\right)$ terhadap peubah kinerja karyawan $\left(\mathrm{Y}_{2}\right)$ dapat dilihat dari tingkat probabilitas yang dimiliki peubah tersebut, yaitu sebesar 0.000, sedangkan besarnya pengaruh peubah iklim kerja organisasi $\left(\mathrm{Y}_{1}\right)$ terhadap peubah kinerja karyawan $\left(\mathrm{Y}_{2}\right)$ berdasarkan tabel regresi, yaitu sebesar 0.840 yang menunjuk pada angkaangka tersebut, maka dapat dijelaskan bahwa:

Peubah iklim kerja organisasi $\left(\mathrm{Y}_{1}\right)$ terhadap kinerja karyawan $\left(\mathrm{Y}_{2}\right)$, keputusannya adalah $\mathrm{H}_{0}$ ditolak, yang artinya adalah terdapat pengaruh yang signifikan. Hal ini ditunjukkan dengan tingkat probabilitas dari peubah iklim kerja organisasi $\left(\mathrm{Y}_{1}\right)$ sebesar 0.000 dimana nilai ini lebih kecil dari $0.05(\mathrm{P}<0.05)$.

Peubah iklim kerja organisasi $\left(\mathrm{Y}_{1}\right)$ mempunyai pengaruh sebesar 0.840 terhadap peubah kinerja karyawan $\left(\mathrm{Y}_{2}\right)$. Dari data di atas maka hipotesis yang menyatakan bahwa ada pengaruh bermakna peubah iklim kerja organisasi $\left(\mathrm{Y}_{1}\right)$ terhadap peubah kinerja karyawan $\left(\mathrm{Y}_{2}\right)$ dapat diterima. 


\section{Ada Pengaruh Bermakna Peubah Gaya Kepemimpinan $\left(X_{1}\right)$ Terhadap Peubah Iklim Kerja Organisasi $\left(\mathbf{Y}_{1}\right)$}

Pengaruh langsung peubah gaya kepemimpinan $\left(\mathrm{X}_{1}\right)$ terhadap peubah iklim kerja organisasi $\left(\mathrm{Y}_{1}\right)$ dapat dilihat dari tingkat probabilitas yang dimiliki peubah tersebut, yaitu sebesar 0.000, sedangkan besarnya pengaruh peubah gaya kepemimpinan $\left(\mathrm{X}_{1}\right)$ terhadap peubah iklim kerja organisasi $\left(\mathrm{Y}_{1}\right)$ berdasarkan tabel regresi, yaitu sebesar 0.562. Menunjuk pada angka-angka tersebut, maka dapat dijelaskan bahwa:

Peubah gaya kepemimpinan $\left(\mathrm{X}_{1}\right)$ terhadap peubah iklim kerja organisasi $\left(\mathrm{Y}_{1}\right)$, keputusannya adalah $\mathrm{H}_{0}$ ditolak, yang artinya terdapat pengaruh yang signifikan. Hal ini ditunjukkan dengan tingkat probabilitas dari peubah gaya kepemimpinan $\left(\mathrm{X}_{1}\right)$ sebesar 0.000 dimana nilai ini lebih kecil dari 0.05 $(\mathrm{P}<0.05)$.

Peubah gaya kepemimpinan $\left(\mathrm{X}_{1}\right)$ mempunyai pengaruh sebesar 0.562 terhadap peubah iklim kerja organisasi $\left(\mathrm{Y}_{1}\right)$. Dari data tersebut maka hipotesis yang menyatakan bahwa ada pengaruh bermakna peubah gaya kepemimpinan $\left(\mathrm{X}_{1}\right)$ terhadap peubah iklim kerja organisasi $\left(\mathrm{Y}_{1}\right)$ dapat diterima.

\section{Ada Pengaruh Bermakna Peubah Gaya Kepemimpinan $\left(\mathbf{X}_{2}\right)$ Terhadap Peubah Iklim Kerja Organisasi $\left(\mathbf{Y}_{1}\right)$}

Pengaruh langsung peubah situasi kepemimpinan $\left(\mathrm{X}_{2}\right)$ terhadap peubah kepuasan kerja karyawan $\left(\mathrm{Y}_{1}\right)$ dapat dilihat dari tingkat probabilitas yang dimiliki peubah tersebut, yaitu sebesar 0.000 , sedangkan besarnya pengaruh peubah situasi kepemimpinan $\left(\mathrm{X}_{2}\right)$ terhadap peubah iklim kerja organisasi $\left(\mathrm{Y}_{1}\right)$ berdasarkan tabel regresi, yaitu sebesar 0.429. Menunjuk pada angkaangka tersebut, maka dapat dijelaskan bahwa:

Peubah situasi kepemimpinan $\left(\mathrm{X}_{2}\right)$ terhadap peubah iklim kerja organisasi ( $\left.\mathrm{Y}_{1}\right)$, keputusannya adalah $\mathrm{H}_{0}$ ditolak, yang artinya terdapat pengaruh yang signifikan. Hal ini ditunjukkan dengan tingkat probabilitas dari peubah situasi kepemimpinan $\left(\mathrm{X}_{2}\right)$ sebesar 0.000 dimana nilai ini lebih kecil dari $0.05(\mathrm{P}<0.05)$.

Peubah situasi kepemimpinan $\left(\mathrm{X}_{2}\right)$ mempunyai pengaruh sebesar 0.429 terhadap peubah iklim kerja organisasi $\left(\mathrm{Y}_{1}\right)$. Dari data di atas maka hipotesis yang menyatakan bahwa ada pengaruh bermakna situasi kepemimpinan $\left(\mathrm{X}_{2}\right)$ terhadap iklim kerja organisasi $\left(\mathrm{Y}_{1}\right)$ dapat diterima. 
Ada Pengaruh Peubah Iklim Kerja Organisasi $\left(Y_{1}\right)$ Secara Tidak Langsung Mempengaruhi Hubungan Peubah Gaya Kepemimpinan $\left(X_{1}\right)$ terhadap Peubah Kinerja Karyawan $\left(Y_{2}\right)$ Secara Bermakna

Berdasarkan hasil perhitungan koefisien path pengaruh tidak langsung, diketahui bahwa besarnya pengaruh peubah gaya kepemimpinan $\left(\mathrm{X}_{1}\right)$ terhadap peubah kinerja karyawan $\left(\mathrm{Y}_{2}\right)$ melalui peubah iklim kerja organisasi $\left(\mathrm{Y}_{1}\right)$, yaitu sebesar 0,472. Berdasarkan lintasan pengaruh seperti yang tampak pada gambar model path dapat diketahui bahwa peubah gaya kepemimpinan $\left(\mathrm{X}_{1}\right)$ merupakan lintasan yang berpengaruh signifikan terhadap peubah iklim kerja organisasi $\left(\mathrm{Y}_{1}\right)$, di sisi lain peubah iklim kerja organisasi $\left(\mathrm{Y}_{1}\right)$ juga merupakan lintasan yang berpengaruh signifikan terhadap peubah kinerja karyawan $\left(\mathrm{Y}_{2}\right)$ sehingga hipotesis yang menyatakan ada pengaruh iklim kerja organisasi secara tidak langsung memengaruhi hubungan peubah gaya kepemimpinan $\left(X_{1}\right)$ terhadap peubah kinerja karyawan $\left(\mathrm{Y}_{2}\right)$ secara bermakna dapat diterima.

Ada Pengaruh Peubah Iklim Kerja Organisasi $\left(\mathbf{Y}_{1}\right)$ Secara Tidak Langsung Mempengaruhi Peubah Situasi Kepemimpinan ( $\left.\mathbf{X}_{2}\right)$ Terhadap Peubah Kinerja Karyawan $\left(Y_{2}\right)$ Secara Bermakna

Berdasarkan hasil perhitungan koefisien path pengaruh tidak langsung, diketahui bahwa besarnya pengaruh peubah situasi kepemimpinan $\left(\mathrm{X}_{2}\right)$ terhadap peubah kinerja karyawan $\left(\mathrm{Y}_{2}\right)$ melalui peubah iklim kerja organisasi $\left(\mathrm{Y}_{1}\right)$, yaitu sebesar 0.360 . Berdasarkan lintasan pengaruh seperti yang tampak pada gambar model path dapat diketahui bahwa peubah situasi kepemimpinan $\left(\mathrm{X}_{2}\right)$ merupakan lintasan yang berpengaruh signifikan terhadap peubah iklim kerja organisasi $\left(\mathrm{Y}_{1}\right)$, di sisi lain peubah iklim kerja organisasi $\left(\mathrm{Y}_{1}\right)$ merupakan lintasan yang berpengaruh signifikan terhadap peubah kinerja karyawan $\left(\mathrm{Y}_{2}\right)$ sehingga hipotesis yang menyatakan ada pengaruh iklim kerja organisasi $\left(\mathrm{Y}_{1}\right)$ secara tidak langsung memengaruhi hubungan peubah situasi kepemimpinan $\left(\mathrm{X}_{2}\right)$ terhadap peubah kinerja Karyawan $\left(\mathrm{Y}_{2}\right)$ secara bermakna diterima.

\section{KESIMPULAN DAN SARAN}

\section{Kesimpulan}

Pengaruh langsung antara peubah gaya kemimpinan $\left(\mathrm{X}_{1}\right)$, situasi kepemimpinan $\left(\mathrm{X}_{2}\right)$, terhadap peubah kinerja karyawan $\left(\mathrm{Y}_{2}\right)$, maka dapat disimpulkan bahwa: (1) Peubah gaya kemimpinan $\left(\mathrm{X}_{1}\right)$ berpengaruh positif dan signifikan terhadap kinerja karyawan $\left(\mathrm{Y}_{2}\right)$. (2) Peubah situasi kepemimpinan $\left(\mathrm{X}_{2}\right)$ berpengaruh positif dan signifikan terhadap kinerja karyawan $\left(\mathrm{Y}_{2}\right)$.

Hasil analisis path pengaruh langsung antara peubah gaya kemimpinan $\left(\mathrm{X}_{1}\right)$, situasi kepemimpinan $\left(\mathrm{X}_{2}\right)$, terhadap peubah iklim kerja organisasi $\left(\mathrm{Y}_{1}\right)$, maka dapat disimpulkan bahwa: (1) Peubah gaya kemimpinan $\left(\mathrm{X}_{1}\right)$ 
berpengaruh positif dan signifikan terhadap peubah iklim kerja organisasi $\left(\mathrm{Y}_{1}\right)$. Hal ini menunjukkan bahwa gaya kemimpinan, khususnya pada tingkat life Skill mendapatkan support yang memadai dari narasumber sebagai suri tauladan dalam menjalankan tugas pekerjaannya dan memengaruhi iklim kerja organisasi $\left(\mathrm{Y}_{1}\right)$. Semakin baik gaya kemimpinan $\left(\mathrm{X}_{1}\right)$ bagi responden, maka respon yang didapatkan adalah semakin baiknya atau meningkatnya tanggapan terhadap iklim kerja organisasi pada PT. Berlina Plastik Pandaan.

Peubah situasi kepemimpinan $\left(\mathrm{X}_{2}\right)$ berpengaruh positif dan signifikan terhadap peubah iklim kerja organisasi $\left(\mathrm{Y}_{1}\right)$. Hasil penelitian menunjukkan bahwa apabila situasi kepemimpinan $\left(\mathrm{X}_{2}\right)$ semakin baik, maka semakin baik respon yang diberikan dalam iklim kerja organisasi $\left(\mathrm{Y}_{1}\right)$. Pengaruh yang diberikan oleh situasi kepemimpinan $\left(\mathrm{X}_{2}\right)$ dikatakan signifikan terhadap iklim kerja organisasi $\left(\mathrm{Y}_{1}\right)$. Berdasarkan hasil analisis path pengaruh langsung antara peubah Iklim Kerja Organisasi $\left(\mathrm{Y}_{1}\right)$ dengan peubah Kinerja Karyawan $\left(\mathrm{Y}_{2}\right)$ maka diperoleh bahwa peubah Iklim Kerja Organisasi $\left(\mathrm{Y}_{1}\right)$ menunjukkan pengaruh positif dan signifikan terhadap peubah kinerja karyawan $\left(\mathrm{Y}_{2}\right)$. selanjutnya hasil analisis path pengaruh tidak langsung antara peubah gaya kemimpinan $\left(\mathrm{X}_{1}\right)$, situasi kepemimpinan $\left(\mathrm{X}_{2}\right)$, terhadap peubah kinerja karyawan $\left(\mathrm{Y}_{2}\right)$ melalui pengaruh iklim kerja organisasi $\left(\mathrm{Y}_{1}\right)$, maka dapat disimpulkan bahwa: perhitungan koefisien path pengaruh tidak langsung, diketahui bahwa besarnya pengaruh peubah gaya kemimpinan $\left(\mathrm{X}_{1}\right)$ terhadap kinerja karyawan $\left(\mathrm{Y}_{2}\right)$ melalui peubah iklim kerja organisasi $\left(\mathrm{Y}_{1}\right)$, yaitu sebesar 0.472 . Berdasarkan lintasan pengaruh seperti yang tampak pada gambar model path dapat diketahui bahwa gaya kemimpinan $\left(\mathrm{X}_{1}\right)$ merupakan lintasan yang berpengaruh signifikan terhadap peubah iklim kerja organisasi $\left(\mathrm{Y}_{1}\right)$, di sisi lain peubah iklim kerja organisasi $\left(\mathrm{Y}_{1}\right)$ juga merupakan lintasan yang berpengaruh signifikan terhadap peubah kinerja karyawan $\left(\mathrm{Y}_{2}\right)$ sehingga hipotesis yang menyatakan ada pengaruh peubah iklim kerja organisasi $\left(\mathrm{Y}_{1}\right)$ secara tidak langsung memengaruhi hubungan peubah gaya kemimpinan $\left(\mathrm{X}_{1}\right)$ terhadap peubah kinerja karyawan $\left(\mathrm{Y}_{2}\right)$ secara bermakna dapat diterima. Sedangkan berdasarkan hasil perhitungan koefisien path pengaruh tidak langsung, diketahui bahwa besarnya pengaruh peubah situasi kepemimpinan $\left(\mathrm{X}_{2}\right)$ terhadap peubah kinerja karyawan $\left(\mathrm{Y}_{2}\right)$ melalui peubah iklim kerja Organisasi $\left(\mathrm{Y}_{1}\right)$, yaitu sebesar 0.360 . Berdasarkan lintasan pengaruh seperti yang tampak pada gambar model path dapat diketahui bahwa peubah situasi kepemimpinan $\left(\mathrm{X}_{2}\right)$ merupakan lintasan yang berpengaruh signifikan terhadap peubah iklim kerja organisasi $\left(\mathrm{Y}_{1}\right)$, sedangkan peubah iklim kerja organisasi $\left(\mathrm{Y}_{1}\right)$ merupakan lintasan yang berpengaruh signifikan terhadap peubah kinerja karyawan $\left(\mathrm{Y}_{2}\right)$ sehingga hipotesis yang menyatakan ada pengaruh peubah iklim kerja organisasi secara tidak langsung memengaruhi hubungan peubah situasi 
kepemimpinan $\left(\mathrm{X}_{2}\right)$ terhadap peubah kinerja karyawan $\left(\mathrm{Y}_{2}\right)$ secara bermakna diterima.

\section{Saran}

Adapun saran yang dapat diajukan adalah sebagai berikut: (1) Dari hasil penelitian, peubah gaya kepemimpinan mempengaruhi peubah kinerja karyawan di PT. Berlina Plastik Pandaan, tentunya dari hasil temuan ini dapat ditindak lanjuti untuk berupaya membuat gaya kepemimpinan bisa menjadi lebih disesuaikan dengan perubahan di lapangan, terutama kaitannya pengaruh dari medsos atau model komunikasi. (2) Bagi peneliti yang akan melanjutkan penelitian ini, dapat diyakinkan bahwa akan mendapatkan hasil yang lebih memberikan manfaat jika peubah ditambah, misalnya komitmen, sehingga hasilnya akan bisa lebih cermat.

\section{DAFTAR PUSTAKA}

Arikunto, Suharsimi (2002), Prosedur Penelitian Suatu Pendekatan Praktik, Edisi Revisi V, Cetakan Keduabelas, PT. Rineka Cipta, Jakarta

A.Supratiknya, 1993, Teori-Teori Holistik (Organismik-Fenomenologis), Penerbit Kanisius, Yogyakarta.

Aube, Caroline, Vincent Rousseau \& Estelle M. Morin, 2007, Perceived Organizational Support and Organizational Commitment: The Moderating Effect of Locus of Control and Work Autonomy, Journal of Managerial Psychology, 22(5).

Azuar Juliandi. 2004, Beberapa Faktor Kepuasan Kerja Yang Mempengaruhi Komitmen Organisasi, Program Studi Ilmu Manajemen Program Pasca Sarjana, Universitas Sumatera Utara.

Bagyo, Yupono.2009. Pengaruh Locus of Control terhadap Organizational Citizenship Behavior, Komitmen Organisasional, Motivasi Kerja dan Kinerja Karyawan (Studi Pada Pialang di Perusahaan Sekuritas di Jawa Timur), Disertasi, Universitas Brawijaya Malang.

BPS, Bappenas, UNFPA dan WHO, 2005, Proyeksi Penduduk Indonesia Tahun 2000-2025.

Bungin, Burhan, 2005, Metodologi Penelitian Kuantitatif Komunikasi, Ekonomi, dan Kebijakan Publik serta Ilmu-ilmu Sosial lainnya, Edisi Pertama, Cetakan Pertama, Prenada Media, Jakarta.

Chiu, Kou Shan, 2005, The Linkage Job Performance to Goal Setting, Work Motivation, Team Building, and organizational Commitment in The High-Tech industry in Taiwan, $\mathrm{H}$. Wayene Huizenge Scool of Business and Entreprerements, Nova Southeastern University, Huizenge.

Dwi Setyowati, Wiwik, softskills, lingkungan dan kelompok sebagai model meningkatkan kinerja (study pada kelompok pusat informasi dan konseling (pik) remaja se kota malang), Tesis, STIE Malangkucecwa Malang 
Ferdinant, Agusty, 2002, Structural Equation Modeling dalam Penlitian Manajemen, BP. Undip, Semarang

Gott, Robin L. (2002), Supervisor Integrity as Perceived by Their Subordinates and Locus of Control as Related to Job Satisfaction, Dissertation, Kean University, United States.

Hasibuan, S.P. Malayu, 1996, Organisasi dan Motivasi, Bumi Aksara, Jakarta.

Heny, Daryanto dan Daryanto, Arief. 2006, Motivational Theories and Organisation Design, University of New England, Australia.

http://duniapsikologi.dag dig dug.com/2008/11/27/pengertian-remaja

Kadir, Abdul, 2005, Pengaruh Keadilan Organisasi dan Budaya Organisasi terhadap Kepuasan Gaji, Komitmen Organisasi dan Kinerja, Disertasi, Program Study Administrasi, Universitas Brawijaya.

Luthans, Fred, 2006, Perilaku Organisasi, Geoge Holmes Distinguished Professor of Manajement, University of Nebraska, Penerbit Andi, Yogyakarta.

Maslow, A. H. 1954. Motivation and personality. New York: Harper \& Row.dalam Introduction to special Topik Forum the Future of Work Motivation Theory, Richard M Steers dan Richard T Mowday, Universitas Oregon, Academy of Management Review, 2004, Vol. 29, No. 3, 379-387.

Mathis. L. Robert \& John H. Jackson, 2006, Human Resource Management, $9^{\mathrm{TH}}$ Edition, Jimmy Sadeli, Salemba Empat, Jakarta.

M.Masri Muadz dan kawan-kawan, 2010, Ketrampilan Hidup (life Skills), BKKBN, Direktorat Remaja dan Perlindungan Hak-hak Reproduksi, Jakarta.

M.Masri Muadz dan kawan-kawan, 2009, Panduan Pengelolaan, Pusat Informasi dan Konseling Remaja (PIK Remaja), BKKBN, Direktorat Remaja dan Perlindungan Hak-hak Reproduksi, Jakarta.

M.Masri Muadz dan kawan-kawan, 2010, Penyiapan Kehidupan Berkeluarga Bagi Remaja, BKKBN, Direktorat Remaja dan Perlindungan Hak-hak Reproduksi, Jakarta.

Mulyono dan Latifun, 2002, Kesehatan Mental; Konsep dan Penerapan, Universitas Muhamadiyah, Malang.

Papulova, Emilia \& Suzana Papulova, 2005, Performance Management and Performance Measures, University of Economics in Bratislava, Slovac Republic.

Rita L Atkinson dkk., terjemahan, 2001, Perngantar Psikologi, edisi kesebelas, jilid 1, Interlaksakna, PO Box 238, Batam Centre, Jakarta.

Rivai dan Sagala, 2009, Manajemen Sumber Daya Manusia Untuk Perusahaan, TE RajaGrafindo Persada, Jakarta.

Robbins, P. Stephen dan Neui Barnwell, 2002, Organization Theory, 4th, Pearson Education Australia, Sydney. 
Sarwono, Jonathan. 2007, Analisis Jalur Untuk Riset Bisnis dengan SPSS, Yogyakarta: ANDI.

Sanusi, Anwar (2003), Metodologi Penelitian Praktis Untuk Ilmu Sosial dan Ekonomi, Edisi Pertama, Cetakan Pertama, Penerbit Buntara Media, Malang.

Singarimbun, Masri dan Sofian Effendi. 1995. Metode Penelitian Survei. Jakarta: LP3ES.

Sugiono. 2008. Metode Penelitian Kuantitatif Kualitatif dan $R \& D$. Alfabeta. Bandung

Tang, T.L.P.,Yuh-Jia Chendan Sutanto, Toto, 2008, Bad apples in bad (business) barrels: The love of money, machiavellianism, risk tolerance, and inithical behavior. Management Decision. Vol.46 No 2, pp.243-263.

Undang-undang No. 23 Tahun 1997 tentang Pengelolaan Lingkungan Hidup, Departemen Lingkungan Hidup, Republik Indonesia.

Vitrie Winastri dan kawan-kawan, 2010, Pendalaman Materi, Membantu Remaja Memahami Dirinya, Penerbit Direktorat Remaja dan Perlindungan Hak-hak Reproduksi, BKKBN, Jakarta.

Wood at all, 'A Global Perspective, Organisational Behaviour, 2 nd Edition, John Wiley \& Sons Australia, Ltd., 2001.

www.eiconsortium.org; diakses Soft Skills, IQ, EI dan Keterkaitannya dengan Unjuk Kerja: Merubah Paradigma Pendidikan (2) Ditulis oleh Aries Musnandar , 2011. 